\title{
Reducing Deviant Behavior through Workplace Spirituality and Job Satisfaction
}

\author{
Aminah Ahmad ${ }^{1}$ \& Zoharah Omar ${ }^{2}$ \\ ${ }^{1}$ Institute for Social Science Studies, Universiti Putra Malaysia, Malaysia \\ ${ }^{2}$ Department of Professional Development and Continuing Education, Faculty of Educational Studies, Universiti \\ Putra Malaysia, Malaysia \\ Correspondence: Aminah Ahmad, Institute for Social Science Studies, Universiti Putra Malaysia, 43400 UPM \\ Serdang, Selangor Darul Ehsan, Malaysia. Tel: 60-38-947-1871; 60-12-368-3411. E-mail: aminah@upm.edu.my; \\ aminahahmad49@gmail.com
}

Received: July 4, 2014 Accepted: September 23, 2014 Online Published: September 29, 2014

doi:10.5539/ass.v10n19p107 URL: http://dx.doi.org/10.5539/ass.v10n19p107

\begin{abstract}
Despite the growing number of studies on workplace spirituality, there is still lack of studies that have explored the relationships between workplace spirituality, job attitudes and behaviors. The purpose of this paper is to propose a model on the relationship between workplace spirituality and workplace deviant behaviour with job satisfaction as a mediator. Workplace spirituality is expected to correlate negatively with workplace deviant behaviour and positively with job satisfaction, and job satisfaction is expected to correlate negatively with workplace deviant behaviour. Drawing from social control theory, social exchange theory and previous literature, we hypothesize that job satisfaction mediates the relationship between workplace spirituality and workplace deviant behaviour. According to this proposed model, an employee who experienced workplace spirituality is more likely to be satisfied with work and will not engage in workplace deviant behaviour. Given the potential effect of workplace spirituality on workplace deviant behaviour via job satisfaction, there is a need for organizations to create a culture of spirituality at the workplace.
\end{abstract}

Keywords: job satisfaction, workplace spirituality, deviant behavior

\section{Introduction}

Deviant workplace behaviour (WDB) among employees is a common problem in work organizations. WDB is defined as "voluntary behavior that violates significant organizational norms and in so doing threatens the wellbeing of an organization, its members, or both" (Robinson \& Bennett, 1995, p. 556). According to Robinson and Bennett (1995) deviant behaviors vary along two dimensions namely, minor versus serious deviance, and interpersonal versus organizational deviance. Examples of minor deviant behaviours include deliberately working slow, leaving the office early and showing favouritism, while examples of serious deviant behaviors include stealing from the company, accepting kickbacks, and endangering co-workers (Robinson \& Bennett, 2000). Deviant behaviours may also include abuse of privileges (Greenberg, 1993), and absenteeism (Kidwell \& Bennett, 1993). Besides the term workplace deviant behaviour, there are various terms used to denote WDB such as noncompliant behavior (Puffer, 1987), organizational misbehavior (Vardi \& Wiener, 1996), workplace aggression (Baron \& Neuman, 1996; O’Leary-Kelly, Griffin, \& Glew, 1996), and antisocial behaviour (Giacalone \& Greenberg, 1997), counterproductive behavior (Sackett \& Devore, 2001), and insidious behavior (Greenberg, 2010). According to Appelbaum, Iaconi, and Matousek (2007), deviance can be categorized into two categories, namely constructive and destructive deviance. Constructive deviance exists when employees engage in innovative behaviours that are beneficial to organizations, while destructive deviance, which is the focus of this paper, exists when employees intentionally engage in behaviors that are harmful to the organisation as well as its members.

There is a growing interest among researchers in studying WDB because of its increasing prevalence and negative impact on individuals and organizations. Past researchers have reported the negative outcomes associated with workplace deviant behavior (Salin, 2003). The impact of WDB on victims include stress-related problems (Appelbaum \& Matousek, 2007), while its impact on organizations include decreased employee commitment and productivity, as well as higher turnover rate and absenteeism (Hoel \& Salin, 2003; Keashly \& 
Jagatic, 2003). Besides the social cost associated with WDB, the prevalence of deviant behavior deserves attention considering the financial cost associated with it. For example theft and fraud is the fastest growing form of WDB in the U.S. and such behaviors have been estimated to cost $\$ 50$ billion annually (Coffin, 2003). In a study on employee theft conducted in 32 countries across Asia Pacific countries, Europe, and North America, employee theft has caused more than one-third of retail shrinkage (Bamfield, 2007). Recognizing the economic as well as the social cost associated with WDB, it is pertinent to further examine the factors that predict WDB.

Previously, studies on deviant behaviour have focused on personality or dispositional factors (e.g., $\mathrm{Ng} \mathrm{\&}$ Feldman, 2008; O’Neill \& Hastings, 2011), organizational factors (e.g., Henle, 2005), work-related factors (e.g., Ferguson, 2007), and ethical ideology (e.g., Henle, Giacalone, \& Jurkiewicz, 2005) as antecedents or predictors of deviant behaviour at the workplace. However, only a few studies have focused on workplace spirituality as a key factor that could influence employee deviant behaviour, despite evidence from previous studies demonstrating spirituality as an important element in the lives of individuals (James, Miles, \& Mullins, 2011). Workplace spirituality refers to "the recognition that employees have an inner life that nourishes and is nourished by meaningful work that takes place in a community" (Ashmos \& Duchon, 2000, p. 137). Spirituality in the workplace according to Gupta, Kumar, and Singh (2013) is about employees who have a common connection and togetherness with other colleagues in their work unit. Similarly, according to Harrington (2004) "spirituality is about employees sharing and experiencing some common attachment, attraction, and togetherness with each other within their work unit and the organization as a whole" (pp. 33-34). Ashmos and Duchon (2000) identified seven dimensions of spirituality. However, three of these dimensions, namely having a deep sense of purpose in one's work or "meaningful work" (individual level), having a deep connection to others or a "sense of community" (group level), and experiencing a strong sense of "alignment with the organization's values" (organization level) have been considered as important in earlier studies (e.g. Milliman, Czaplewski, \& Ferguson, 1999; Mitroff \& Denton, 1999; Milliman, Czaplewski, \& Ferguson, 2003).

Previously, spirituality and management have been thought to be incompatible, but presently they have become linked together (James, Miles, \& Mullins, 2011). Academics and practitioners now realize that promoting workplace spirituality can help improve employee performance (James, Miles, \& Mullins, 2011). Several scholars contend that besides improving performance, spirituality can lead to higher productivity, greater contribution to the organization, better decision-making, increased problem solving capabilities, higher intuitive capacities, greater creativity, and overall more efficient use of human and material resources (Weitz, Vardi, \& Setter, 2012). If appropriately managed, workplace spirituality may serve as a personal mechanism for controlling individual behaviour at work (James, Miles, \& Mullins, 2011).

In this highly competitive environment, generally, it is essential that every organization attain high profits and a big market share. Because of this pressure, employees are expected to work longer hours and to take fewer holidays since employers are setting targets which are very high and unrealistic for their employees. This situation results in greater anxiety and stress among employees which may in turn result in poor job performance, poor family and social relations, and poor health, which in turn reduce the level of employees job satisfaction (Gupta, Kumar, \& Singh, 2013). Employers have realized that employee satisfaction does not depend on material rewards alone and that employees want more than that (Gupta, Kumar, \& Singh, 2013). Spirituality can play an important role in overcoming this problem because according to Giacolone and Jurkiewics (2010) it promotes feelings of satisfaction through transcendence. Besides this, research supports the notion that spirituality programs in an organization result in positive outcomes, such as job satisfaction besides among others increased commitment and productivity, and improved coping with work-related stress (Reave, 2005; Chand \& Koul, 2012; Chen \& Yang, 2012; Fry, Hannah, Noel, \& Walumbwa, 2011; Giacalone \& Jurkiewicz, 2003; Hong, 2012). Despite these positive outcomes, research relating to WDB is still limited. Most literature on workplace spirituality are generally more theoretical as opposed to empirical and relatively few studies have established the link between workplace spirituality and work attitudes (Gupta, Kumar, \& Singh, 2013). Although, researchers have stressed the importance of studies on the impact of spirituality on organizational outcomes, such studies are still considered inadequate (e.g. Duchon \& Plowman, 2005; James, Miles, \& Mullins, 2011).

\section{Theories}

\subsection{Social Exchange Theory}

Social exchange theory (Homans, 1961) provides one possible explanation to explain the relationship between job satisfaction and WDB. This theory suggests that social behavior is the outcome of an exchange process. The aim of this exchange process is to maximize benefits and reduce costs. According to this theory, individuals assess the likely benefits and risks of such relationships. In situations where the risks outweigh the rewards, 
individuals will terminate that relationship. Central to this theory is the notion that there is a greater likelihood that any interaction that brings about approval from another person will be repeated compared with an interaction that elicits disapproval. This exchange process brings satisfaction when individuals receive fair returns from the relationships. Employees who experience job dissatisfaction might engage in WDB as a means of reacting against their employers for providing a non-conducive work environment. Another possible explanation is that dissatisfied employees tend to care less about losing their jobs and hence are keen to engage in behaviors that might jeopardize their employment. On the other hand, satisfied employees, tend to avoid engaging in WDB to avoid being fired.

\subsection{Social Control Theory}

According to the social control theory (Hirschi, 1969), individuals are prevented from engaging in deviant behavior through their bondage with social institutions such as family and religion, as well as workplace spirituality which Jurkiewicz and Giacalone (2004) defined as a framework of organizational values. This theory asserts that bonds to social institutions serve to reduce one's propensity for deviant behaviour. Hence, this theory posits that crime or deviance occurs when such bonds are weakened or are not well established. One of the four elements of this social bond is the belief in conventional norms. When this element of the bond is weak, there is a greater likelihood for the individual to become "free" and hence engage in deviant behavior. Conversely, when this attachment or bonding is strong it reinforces an employee's purpose or meaningfulness of work which could in turn reduce deviant behaviour. Unlike other theories that attempt to explain why individuals are involved in deviant behaviour, control theories take the contrary approach, questioning why people resist from offending (Akers \& Sellars, 2004). As a result, WDB can be viewed as a possibility for all employees within the organization, refrained only by those who attempt to maintain social bonds.

\section{Literature Review}

\subsection{Relationship between Workplace Spirituality and Job Satisfaction}

The relationship between workplace spirituality and job satisfaction has not been much studied (Duffy, 2006), although there has been an increasing interest in studying this relationship. An earlier study conducted by Milliman et al. (2003) among part-time employees revealed significant positive relationships between certain dimensions of spirituality and job satisfaction. Later, other studies have also shown that in organizations where spirituality is respected, employees experience greater job satisfaction (Pawar, 2009; Chawla \& Guda, 2010; Altaf \& Awan, 2011; Lazar, 2010). Hence, employees whose spiritual needs are fulfilled tend to be more satisfied with their jobs.

\subsection{Relationship between Workplace Spirituality and Deviant Behaviour}

The recognition of the need for spirituality in the workplace could be one way to help decrease WDB among employees since spirituality has the potential to act as a personal control that assists employees gauge their behavior at work (James, Miles, \& Mullins, 2011). Weitz, Vardi, \& Setter (2012) reported that workplace spirituality was significantly and negatively correlated with deviant behaviour. A qualitative research by Sulaiman and Bhatti (2013) revealed that being spiritually strong would help to generate positive behavior and deviant-free environment in an organization. In addition, organizations that support spiritual and caring work environments benefit from employees who are not only more committed and productive, but are less prone to engagement in WDB. Hence, it can be argued that a satisfied employee whose spiritual needs have been fulfilled will not engage in WDB but instead tend to be a better performer.

\subsection{Relationship between Job Satisfaction and Workplace Deviant Behaviour}

Several studies have indicated a relationship between job satisfaction and WDB. A study conducted by Bennett and Robinson (2003) has shown that job dissatisfaction is linked to deviant behavior. This similar linkage has been reported by Bowling (2010). When employees are dissatisfied with their jobs, they tend to display more WDB as a means of releasing emotional tension (Srivastava, 2012). A meta-analysis by Dalal (2005) revealed that job satisfaction is negatively correlated with WDB. Based on the findings of previous studies it can be expected that dissatisfied employees may engage in deviant behaviors such as destructive rumors, poor service, absenteeism, theft and sabotage of equipment.

\section{The Model}

Grounded in social exchange theory (Blau, 1964; Homans, 1961) and social control theory (Hirschi, 1969), we develop a mediation model involving workplace spirituality as an antecedent, WDB as an outcome and job satisfaction as the mediator. Besides using these theories for model development, we integrate the literature on spirituality, job satisfaction and organizational commitment. The theories and literature as discussed earlier tend 
to support the link between spirituality in organizations, job satisfaction and WDB. The model postulates that workplace spirituality could help increase employee job satisfaction level and employees who are more satisfied tend to engage less in WDB. In other words, WDB has the potential to be reduced by workplace spirituality through job satisfaction.

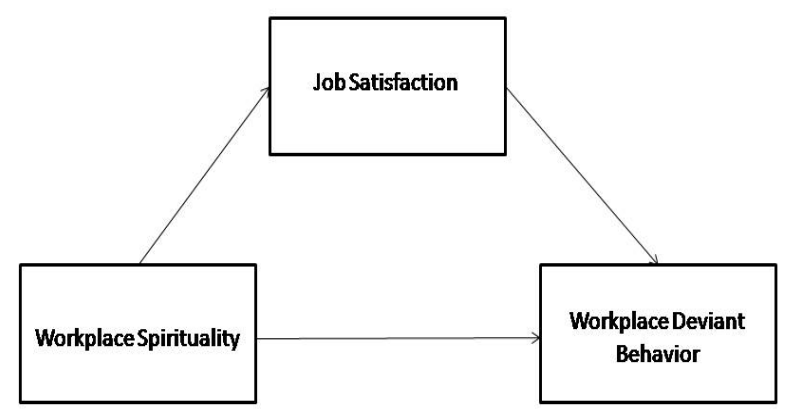

Figure 1. A mediation model on workplace spirituality, job satisfaction and workplace deviant

\section{Conclusion}

This model suggests that spirituality plays an important role in organizations and influences employee attitude and behavior. By providing opportunities to satisfy employees' spiritual needs at work, employers may enhance employee job satisfaction, and in turn reduce WDB. Such opportunities can be made available by creating a culture of spirituality at the workplace which could help overcome the prevailing problem of WDB.

\section{References}

Agnew, R. (1991). A longitudinal test of social control theory and delinquency. Journal of Research in Crime and Delinquency, 28(2), 126-156. http://dx.doi.org/10.1177/0022427891028002002

Akers, R. L., \& Sellers, C. S. (2004). Criminological theories: Introduction, evaluation, and application (4th ed.). Los Angeles: Roxbury Publishing. ISBN-13: 978-0199844487

Altaf, A., \& Awan, M. A. (2011). Moderating affect of workplace spirituality on the relationship of job overload \& job satisfaction. Journal of Business Ethics, 104(1), 93-99. http://dx.doi.org/10.1007/s10551-011-0891-0

Appelbaum, S. H., Iaconi, G.. D., \& Matousek, A. (2007). Positive and negative deviant workplace behaviors: Causes, impact, and solutions. Corporate Governance, 7(5), 86-598. http://dx.doi.org/10.1108/1472070 0710827176

Ashmos, D., \& Duchon, D. (2000). Spirituality at work. Journal of Management Inquiry, 9(2), 134-145. http://dx.doi.org/10.1177/105649260092008

Bamfield, J. (2007). Global retail theft barometer. Nottingham: Centre for Retail Research.

Baron, R. A., \& Neuman, J. H. (1996). Workplace violence and workplace aggression: Evidence on their relative frequency and potential causes. Aggressive behavior, 22(3), 161-173. http://dx.doi.org/10.1002/(SICI)1098 -2337(1996)22:3<161::AID-AB1>3.0.CO;2-Q

Bennett, R. J., \& Robinson, S. L. (2003). The past, present, and future of workplace deviance research. In J. Greenberg (Ed.), Organizational behavior: The state of the science. Lawrence Erlbaum Associates.

Blau, P. M. (1964). Exchange \& power in social life transaction. ISBN 9780887386282.

Bowling, N. A. (2010). Effects of job satisfaction and conscientiousness on extra-role behaviors. Journal of Business and Psychology, 25(1), 119-130. http://dx.doi.org/10.1007/s10869-009-9134-0

Chand, P., \& Koul, H. (2012). Workplace spirituality, organizational emotional ownership and job satisfaction as moderators in coping with job stress. Decision Making, 9(10). Retrieved from http://psrcentre.org/images/ extraimages/312133.pdf

Chawla, V., \& Guda, S. (2010). Individual spirituality at work and its relationship with job satisfaction, propensity to leave and job commitment an exploratory study among sales professionals. Journal of Human Values, 16(2), 157-167. http://dx.doi.org/10.1177/097168581001600203

Chen, C. Y., \& Yang, C. F. (2012). The impact of spiritual leadership on organizational citizenship behavior: A multi-sample analysis. Journal of Business Ethics, 105(1), 107-114. 
Coffin, B. (2003). Breaking the silence on white collar crime. Risk Management, 50(8), 6. Retrieved from http://www.questia.com/magazine/1G1-107762284/breaking-the-silence-on-white-collar-crime

Dalal, R. S. (2005). A meta-analysis of the relationship between organizational citizenship behavior and counterproductive work behavior. Journal of Applied Psychology, 90(6), 1241-1255. http://dx.doi.org/10. 1037/0021-9010.90.6.1241

Duchon, D., \& Plowman, D. A. (2005). Nurturing the spirit at work: Impact on work unit performance. The Leadership Quarterly, 16(5), 807-833. http://dx.doi.org/10.1016/j.leaqua.2005.07.008

Duffy, R. D. (2006). Spirituality, religion, and career development: Current status and future directions. The Career Development Quarterly, 55(1), 52-63. http://dx.doi.org/10.1002/j.2161-0045.2006.tb00004.x

Ferguson, M. J. (2007). Knowledge creation diffusion utilization (Unpublished doctoral's thesis). Nashville, TN.

Fry, L. W., Hannah, S. T., Noel, M., \& Walumbwa, F. O. (2011). Impact of spiritual leadership on unit performance. The Leadership Quarterly, 22(2), 259-270. http://dx.doi.org/10.1016/j.leaqua.2011.02.002

Giacalone, R. A., \& Greenberg, J. (1997). Antisocial behaviors in organizations. Thousand Oaks, CA: Sage.

Giacalone, R. A., \& Jurkiewicz, C. L. (2003). Toward a science of workplace spirituality. In R. A. Giacalone, \& C. L. Jurkiewicz (Eds.), Handbook of workplace spirituality and organizational performance (pp. 3-26). Armonk, NY: M.E. Sharpe.

Greenberg, J. (1993). Stealing in the name of justice: Informational and interpersonal moderators of theft reactions to underpayment inequity. Organizational Behavior and Human Decision Processes, 54, 81-103. http://dx.doi.org/10.1006/obhd.1993.1004

Greenberg, J. (2010). Insidious workplace behavior. New York, NY: Routledge. ISBN 9781848728585.

Gupta, M., Kumar, V., \& Singh, M. (2013). Creating satisfied employees through workplace spirituality: A study of the private insurance sector in Punjab (India). Journal of Business Ethics, 122, 1-10. http://dx.doi.org/10.1007/s10551-013-1756-5

Henle, C. A. (2005). Predicting workplace deviance from the interaction between organisational justice and personality. Journal of Managerial Issues, 17(2), 247-63. Retrieved from http://www.jstor.org/discover/ 10.2307/40604498? uid $=6552064 \&$ uid $=3738672 \&$ uid $=2$ \&uid $=3 \&$ uid $=67 \&$ uid $=6552000 \& u i d=62 \&$ sid $=211$ 04215179931

Henle, C. A., Giacalone, R. A., \& Jurkiewicz, C. L. (2005). The role of ethical ideology in workplace deviance. Journal of Business Ethics, 56(3), 219-230. http://dx.doi.org/10.1007/s10551-004-2779-8

Hirschi, T. (1969). Causes of delinquency. Berkeley, CA: University of California Press. ISBN 0765809001.

Hoel, H. \& Salin, D. (2003). Organisational antecedents of workplace bullying. In S. Einarsen, H. Hoel, D. Zapf \& C. Cooper (Eds.), Bullying and emotional abuse in the workplace: International perspectives in research and practice. London: Taylor \& Francis. ISBN-10: 0415253594.

Hollinger, R. C., \& Davis, J. L. (2003). 2002 National retail security survey: Final report. Gainesville, FL: Security Research Project, University of Florida.

Homans, G. C. (1961). Social behavior: Its elementary form. New York: Harcourt Brace and World.

Hong, Y. J. (2012). Identifying spirituality in workers: A strategy for retention of community mental health professionals. Journal of Social Service Research, 38(2), 175-186. http://dx.doi.org/10.1080/01488376. 2011.615275

James, M. S., Miles, A. K., \& Mullins, T. (2011). The interactive effects of spirituality and trait cynicism on citizenship and counterproductive work behaviors. Journal of Management, Spirituality \& Religion, 8(2), 165-182. http://dx.doi.org/10.1080/14766086.2011.581814

Jurkiewicz, C. L., \& Giacalone, R. A. (2004). A values framework for measuring the impact of workplace spirituality on organizational performance. Journal of business ethics, 49(2), 129-142.

Keashly, L., \& Jagatic, K. (2003). By any other name: American perspectives on workplace bullying. In S. Einarsen, H. Hoel, D. Zapf, \& C. L. Cooper (Eds.), Bullying and emotional abuse in the workplace. International Perspectives in Research and Practice (pp. 31-61). London: Taylor \&Francis. 
Kidwell, R. E., \& Bennett, N. (1993). Employee propensity to withhold effort: A conceptual model to intersect three avenues of research. Academy of Management Review, 18(3), 429-456. http://dx.doi.org/10.2307/ 258904

Klaassen, D. W., Graham, M. D., \& Young, R. A. (2009). Spiritual/religious coping activity: An action. Archive for the Psychology of Religions, 31, 3-33. http://dx.doi.org/10.1163/157361209X371456

Lazar A. (2010). Spirituality and job satisfaction among female Jewish Israeli hospital nurses. Journal of Advanced Nursing, 66(2), 334-344. http://dx.doi.org/10.1111/j.1365-2648.2009.05172.x

Milliman, J., Czaplewski, A. J., \& Ferguson, J. (2003). Workplace spirituality and employee work attitudes: An exploratory empirical assessment. Journal of Organizational Change Management, 16(4), 426-447. http://dx.doi.org/10.1108/09534810310484172

Milliman, J., Ferguson, J., Trickett, D., \& Condemi, B. (1999). Spirit and community at Southwest Airlines: An investigation of a spiritual values-based model. Journal of Organizational Change Management, 12(3), 221-233. http://dx.doi.org/10.1108/09534819910273928

Mitroff, I., \& Denton, E. (1999). A spiritual audit of corporate America: Multiple designs for fostering spirituality in the workplace. San Francisco: Iossey-Bass.

Ng, T. W. H., \& Feldman, D. C. (2008). The relationship of age to ten dimensions of job performance. Journal of Applied Psychology, 93(2), 392-423. http://dx.doi.org/10.1037/0021-9010.93.2.392

O’Leary-Kelly, M. A., Griffin, R. W., \& Glew, D. J. (1996). Organization-motivated aggression: A research framework. Academy of management review, 21(1), 225-253. http://dx.doi.org/10.2307/258635

O’Neill, T. A., \& Hastings, S. E. (2011). Explaining workplace deviance behavior with more than just the "Big Five". Personality and Individual Differences, 50(2), 268-273. http://dx.doi.org/10.1016/j.paid.2010.10.001

Pawar, B. S. (2009). Individual spirituality, workplace spirituality and work attitudes: An empirical test of direct and interaction effects. Leadership \& Organization Development Journal, 30(8), 759-777.

Puffer, S.M. (1987). Prosocial behavior, noncompliant behavior, and work performance among commission salespeople. Journal of Applied Psychology, 72, 615-621. http://dx.doi.org/10.1037/0021-9010.72.4.615

Rayner, C., Hoel, H., \& Cooper, C. L. (2002). Workplace bullying: What we know, who is to blame and what can we do? London: Taylor\& Francis. ISBN-13: 978-0415240635.

Reave, L. (2005). Spiritual values and practices related to leadership effectiveness. The leadership quarterly, 16(5), 655-687. http://dx.doi.org/10.1016/j.leaqua.2005.07.003

Robinson, S. L., \& Bennett, R. J. (1995). A typology of deviant workplace behaviors: A multidimensional scaling study. Academy of Management Journal, 38(2), 555-572. http://dx.doi.org/10.2307/256693

Sackett, P. R., \& Devore, C. J. (2001). Counterproductive behaviors at work. In N. Anderson, D. S. Ones, H. K. Sinangil, \& C. Viswesvaran, (Eds.), Handbook of industrial, work and organizational psychology (pp. 145-164). London: Sage.

Salin, D. (2003). Ways of explaining workplace bullying: A review of enabling, motivating and precipitating structures and processes in the work environment. Human Relations, 56(10), 1213-1232.

Srivastava, S. (2012). Workplace passion as a moderator for workplace deviant behaviour-job satisfaction relationship: A comparative study between public sector and private sector managers. Asia-Pacific Journal of Management Research and Innovation, 8(4), 517-523. http://dx.doi.org/10.1177/2319510X13481914

Sulaiman, M., \& Bhatti, O. K. (2013). Workplace deviance and spirituality in Muslim organizations. Asian Social Science, 9(10), 237-246. ISSN 1911-2025.

Vardi, Y., \&Wiener, Y. (1996). Misbehavior in organizations: A motivational framework. Organization science, 7, 151-165. http://dx.doi.org/10.1287/orsc.7.2.151

Weitz, E., Vardi, Y., \& Setter, O. (2012). Spirituality and organizational misbehavior. Journal of Management, Spirituality \& Religion, 9(3), 255-281. http://dx.doi.org/10.1080/14766086.2012.730782

\section{Copyrights}

Copyright for this article is retained by the author(s), with first publication rights granted to the journal.

This is an open-access article distributed under the terms and conditions of the Creative Commons Attribution license (http://creativecommons.org/licenses/by/3.0/). 